\title{
Stimulation of protein secretion in the initial segment of the rat epididymis by fluid from the ram rete testis
}

\author{
S. Sujarit, R. C. Jones, B. P. Setchell*, G. Chaturapanich, M. Lin and \\ J. Clulow
}

Department of Biological Sciences, The University of Newcastle, New South Wales 2308, Australia; and ${ }^{*}$ Department of Animal Sciences, Waite Agricultural Research Institute, University of Adelaide, South Australia 5064, Australia

\begin{abstract}
Summary. Zone $1 \mathrm{~A}$ of the ductus epididymidis was perfused with ovine rete testis fluid (nRTF) and modifications of it, and a synthetic medium (sRTF) based on the inorganic composition of nRTF. There was little fluid transport by the duct mucosa and nRTF stimulated protein secretion. The secretagogue activity was not extracted by charcoal, was sensitive to protease digestion and was present in a portion of nRTF with a molecular weight of $>10000$. The addition of bovine serum albumin to the sRTF stimulated protein secretion, but not to the same extent as equal amounts of protein in nRTF.

Polyacrylamide gel electrophoresis of the perfusates showed that proteins with molecular weights of 19000 (all rats studied), and 22000,30000 and 60000 (at least half the rats studied) were secreted into the perfusion fluids as well as some blood proteins, but the pattern of secretion was not affected by the composition of the perfusion fluid.
\end{abstract}

Keywords: initial segment; rete testis fluid; secretagogue; rat

\section{Introduction}

Benoit (1926) recognized that there is an initial segment in the epdidymis of mammals which is characterized by a tall secretory epithelium with long stereocilia, a wide diameter and a low concentration of spermatozoa in the lumen. The segment is dependent on a luminal connection with the testis even when systemic androgen concentrations are high (Gustafsson, 1966; Moniem et al., 1978; Fawcett \& Hoffer, 1979; Nicander et al., 1983), and it is considered that the segment plays an important role in extratesticular sperm maturation (Jones et al., 1987; Jones \& Clulow, 1987b).

Protein secretion is one of the major functions of the initial segment epithelium; the secretion is dependent on a luminal connection with the testis and some of it becomes associated with the plasmalemma of spermatozoa (Fawcett \& Hoffer, 1979; Jones et al., 1980b; Jones \& Brown, 1982).

This report describes the use of a microperfusion technique to study protein secretion by the initial segment of the rat and the role of fluid collected from the rete testis in regulating the secretion.

\section{Materials and Methods}

Microperfusion. Mature, male Wistar rats (320-460 g) were anaesthetized with sodium 5-ethyl-5(1-methyl propyl)-2: thiobarbiturate (Inactin, Byk Gulden Pharmaceuticals, Konstanz, West Germany) initially administered intraperitoneally at a dose of $100 \mathrm{mg} / \mathrm{kg}$ body mass and subsequently via a cannula in the jugular vein. The rats were supported on a heated table and maintained at $35-36^{\circ} \mathrm{C}$.

The ductus epididymidis was cannulated using 9-0 silk thread (Ethicon, Inc., Johnson \& Johnson, Sydney, Australia), and polyethylene tubing (o.d. $0.61 \mathrm{~mm}$, i.d. $0.28 \mathrm{~mm}$; Dural Plastics \& Engineering, Auburn, NSW, 
Australia) drawn to a tip diameter of $100-120 \mu \mathrm{m}$ and supported by a micromanipulator. The proximal cannula was inserted near the proximal end of zone $1 \mathrm{~A}$ and the distal cannula was inserted into zone $1 \mathrm{~B}$ (near the proximal end) of the epididymis (Reid \& Cleland, 1957) so that $15 \pm 1.6 \mathrm{~cm}$ (mean \pm s.e. from 29 rats) of the duct were perfused. The temperature of the perfused duct was maintained at $32-33^{\circ} \mathrm{C}$ by dropping warm paraffin oil (Fisher Scientific Co., Springfield, NJ, USA) onto its surface from an oil heater.

The duct was perfused at a rate of $0.5 \mu \mathrm{l} / \mathrm{min}$ (Model $341 \mathrm{~A}$ Syringe pump, Sage Instruments, Cambridge, MA, USA) and the perfusate emerging from the distal cannula was collected into a microhaematocrit tube under water saturated paraffin oil stained with Sudan black. The first sample was collected $1.5 \mathrm{~h}$ after perfusion began when all spermatozoa had been flushed from the duct, and samples were accumulated over 2 -h intervals during a $7 \cdot 5$-h period of perfusion, then stored at $-20^{\circ} \mathrm{C}$ until analysis.

Perfusion fluids. $\left[{ }^{3} \mathrm{H}\right]$ Inulin (sp. act. $1 \mu \mathrm{Ci} / \mu \mathrm{l}$; Amersham, Bucks, UK) was added to determine fluid transport across the duct mucosa and so correct for its effect on differences in protein concentration between the perfusion fluid and the perfusate. Fluid transport was expressed as the inulin ratio, calculated as the number of scintillation counts per minute in the perfusate divided by the number of counts in the perfusing fluid.

Rete testis fluid (nRTF) was collected from the ram by cannulation (Suominen \& Setchell, 1972), and stored at $-20^{\circ} \mathrm{C}$ until use. Fluid from the ram rather than the rat was used in order to obtain a sufficient volume for the work. Steroid-free nRTF was prepared using charcoal and dextran T70 (Pharmacia, Uppsala, Sweden) to extract the steroid (Tsonis et al., 1983). High and low molecular weight $\left(M_{\mathrm{r}}\right)$ fractions of nRTF were prepared using an ultrafiltration membrane with a cut-off level of $M_{\mathrm{r}} 10000$ (Centricon 10 Microconcentrator, Amicon Scientific Australia; Division of W. R. Grace \& Co., Fawkner, Victoria). The protein content of the nRTF was concentrated 5-fold in the high $M_{\mathrm{r}}$ fraction of $n R T F$. Protease-digested samples of $n R T F$ were prepared using trypsin (type XI1-S, bovine pancreas: Sigma Chemical Co., St Louis, MO, USA) and $\alpha$-chymotrypsin (type VI, Sigma Chemical Co.), and trypsin inhibitor (Type I-S, Sigma Chemical Co.) as described by Feig et al. (1980). All solutions were adjusted to pH $7 \cdot 1$ by bubbling $5 \%$ carbon dioxide in air through them.

A synthetic solution (sRTF) was prepared containing the same concentrations of inorganic electrolytes as $\mathrm{nRTF}$ (Setchell et al., 1969). It contained $118 \mathrm{~mm}$-sodium chloride, $13 \mathrm{~mm}$-potassium chloride, $1.05 \mathrm{~mm}$-calcium chloride, $0.34 \mathrm{~mm}$-magnesium sulphate, $0.075 \mathrm{~mm}$-sodium dihydrogen phosphate, $8 \mathrm{~mm}$-sodium bicarbonate, $20 \mathrm{~mm}$-Hepes (Sigma), and $0,1.3$ or $3.4 \mu \mathrm{g}$ bovine serum albumin/ $\mu \mathrm{l}$ (BSA, Fraction V: Commonwealth Serum Laboratory, Melbourne, Australia). The $\mathrm{pH}$ was adjusted to $\mathrm{pH} 7 \cdot 1$ with sodium hydroxide and the final osmolality was $290 \mathrm{mosmol} / \mathrm{kg}$.

Analyses of perfusates. $\left[{ }^{3} \mathrm{H}\right]$ Inulin was determined by scintillation spectroscopy and protein was determined quantitatively using Coomassie blue (Bradford, 1976). The rate of secretion of protein was calculated from the difference in protein concentration in the perfusion fluid and the collectate, and the estimate was corrected, using the inulin ratio, for fluid transport across the mucosa of the epididymal duct. Some samples of nRTF and blood plasma, and perfusates of nRTF (4 rats) and sRTF (4 rats) were subjected to denatured, continuous gradient polyacrylamide gel electrophoresis (Jones, 1987).

Structure of epithelium. Some of the rats in which the ductus epididymidis was perfused with nRTF and $\mathrm{sRTF}$ were fixed by perfusing fixatives through the vascular system (Jones et al., 1984) and samples of the ductus epididymidis in zone 1A were taken from the perfused duct and contralateral epididymis. The samples were post-fixed (Jones $e t$ al., 1984), embedded in Spurr's medium and sectioned for light and electron microscopy.

Statistical analysis. Analysis of variance was used to test the statistical significance of the effects of treatment using the variance between animals within treatments as the denominator in the F-tests. Results are presented as means \pm s.e. and the standard errors were calculated from the variance between animals.

Elemental analysis. Samples of perfusion fluid and perfusate from ducts perfused with nRTF (5 rats) and sRTF (5 rats) were analysed for elemental concentrations using electron probe microanalysis (Jones \& Clulow, $1987 \mathrm{a}$ ).

\section{Results}

Perfusing the duct for $7.5 \mathrm{~h}$ with sRTF or nRTF had no effect on the structure of the duct mucosa (Fig. 1).

The mean ( \pm s.e.) inulin ratios for the 8 perfusion fluids shown in Table 1 were respectively $0.92 \pm 0.01,0.96 \pm 0.05,0.92 \pm 0.03,0.96 \pm 0.06,0.96 \pm 0.01,1.13 \pm 0.10,1.00 \pm 0.03$ and $0.95 \pm 0.01$. However, the differences between perfusion fluids were not statistically significant. Further, except for potassium in SRTF there was no significant change during perfusion in the concentration of any of the 7 elements examined (sodium, potassium, chlorine, calcium, magnesium, phosphorus and sulphur). The potassium concentration was $13.46 \pm 0.87$ in sRTF and $9.57 \pm 0.78$ in the perfusate $(P<0.05)$. 

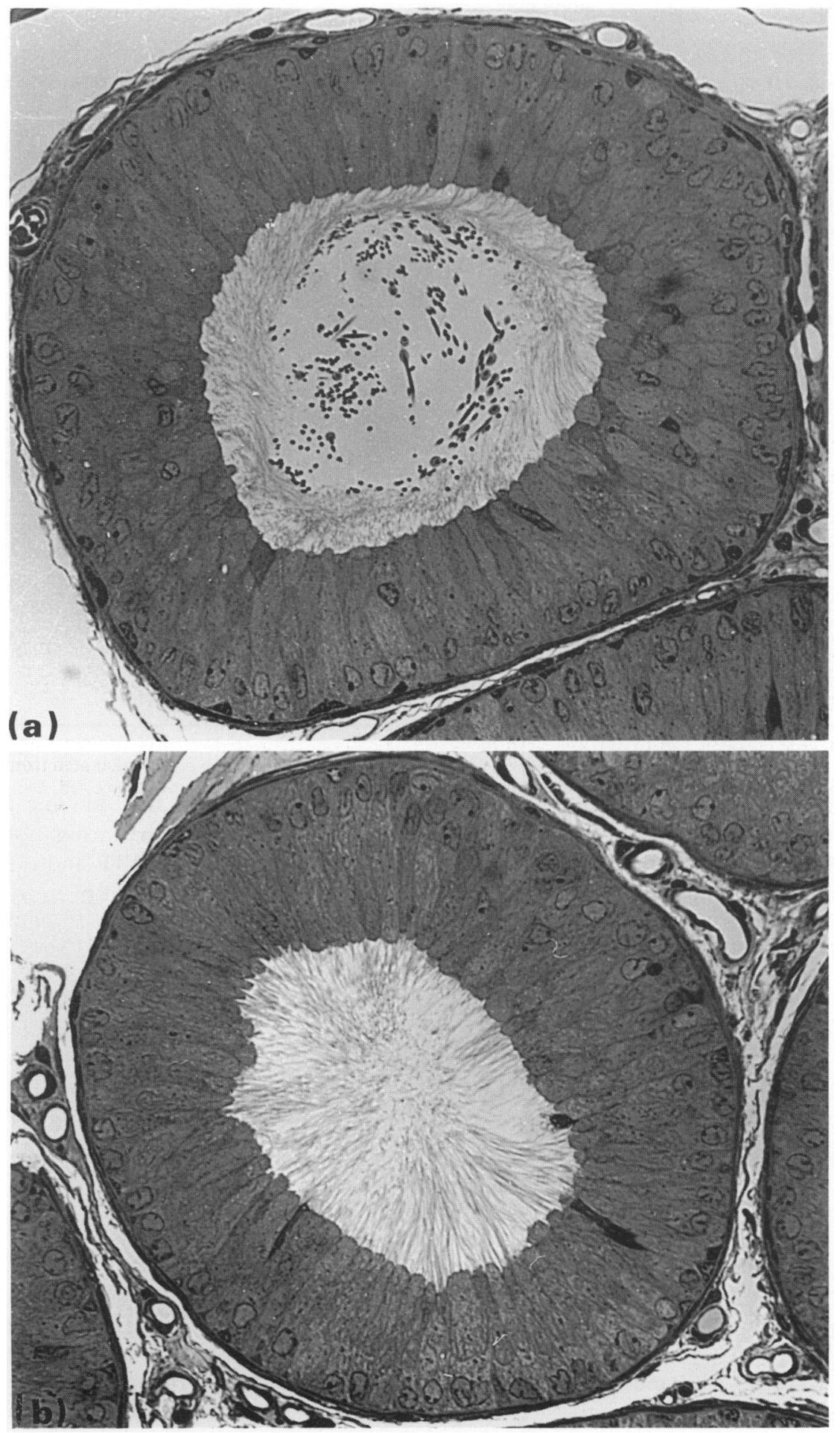

Fig. 1. Light micrographs of cross-sections of zone 1A of the ductus epididymidis of (a) an untreated duct and (b) a duct which had been perfused for $7.5 \mathrm{~h}$ with sRTF. Spurr's resin, toluidine blue staining, $\times 250$. 
Table 1 summarizes the effects on net protein secretion by the ductus epididymidis of perfusing the ductus with $\mathrm{nRTF}, \mathrm{sRTF}$ and various modifications of the fluids. The mean secretion rate into each of the perfusing fluids was much the same during the whole period of perfusion. The mean rate of protein secretion was approximately $3-4$ times greater into the ducts perfused with $n R T F$, the steroid-extracted nRTF and the high $M_{\mathrm{r}}$ fraction of nRTF than with the low $M_{\mathrm{r}}$ fraction of nRTF, the protease digested nRTF or the SRTF $(P<0.001)$. Protein secretion into the unmodified nRTF was much the same as into the steroid-free $\mathrm{nRTF}$, but was about 1.5 times greater into the duct perfused with the high $M_{\mathrm{r}}$ fraction of $\mathrm{nRTF}$ (in which the protein was concentrated; see "Materials and Methods') than into unmodified nRTF $(P<0.05)$.

Table 1. Rate of protein secretion $(\mathrm{ng} / \mathrm{min})$ into zone $1 \mathrm{~A}$ of the rat epididymis during perfusion for $7.5 \mathrm{~h}$ with $\mathrm{nRTF}$, sRTF or various modifications of the fluids

\begin{tabular}{|c|c|c|c|c|c|}
\hline \multirow[b]{2}{*}{ Treatment } & \multirow{2}{*}{$\begin{array}{l}\text { No. of } \\
\text { animals }\end{array}$} & \multicolumn{3}{|c|}{ Time $(h)$ after perfusion started } & \multirow{2}{*}{$\begin{array}{c}\text { Mean for } \\
7.5 \mathrm{~h}\end{array}$} \\
\hline & & $1 \cdot 5-2 \cdot 5$ & $2 \cdot 5-5 \cdot 5$ & $5 \cdot 5-7 \cdot 5$ & \\
\hline \multicolumn{6}{|l|}{ nRTF } \\
\hline (1) Unmodified & 7 & $76 \pm 17$ & $105 \pm 29$ & $97 \pm 19$ & $93 \pm 22$ \\
\hline (2) Steroid-extraction & 4 & $78 \pm 32$ & $123 \pm 67$ & $96 \pm 37$ & $99 \pm 45$ \\
\hline (3) High $M_{\mathrm{r}}$-fraction & 5 & $143 \pm 44$ & $156 \pm 34$ & $137 \pm 39$ & $145 \pm 39$ \\
\hline (4) Low $M_{\mathrm{r}}$-fraction & 3 & $18 \pm 2$ & $19 \pm 4$ & $20 \pm 4$ & $19 \pm 3$ \\
\hline (5) Protease digested & 3 & $36 \pm 18$ & $38 \pm 25$ & $50 \pm 10$ & $41 \pm 18$ \\
\hline \multicolumn{6}{|l|}{ sRTF } \\
\hline (6) $0.0 \mu \mathrm{g} \mathrm{BSA} / \mu \mathrm{l}$ & 8 & $27 \pm 5$ & $27 \pm 3$ & $22 \pm 3$ & $25 \pm 4$ \\
\hline (7) $1.3 \mu \mathrm{g} \mathrm{BSA} / \mu \mathrm{l}$ & 6 & $21 \pm 10$ & $77 \pm 30$ & $37 \pm 22$ & $45 \pm 21$ \\
\hline (8) $3.4 \mu \mathrm{g} \mathrm{BSA} / \mu \mathrm{l}$ & 5 & $72 \pm 18$ & $123 \pm 14$ & $112 \pm 5$ & $102 \pm 12$ \\
\hline
\end{tabular}

Values are means \pm s.e.

The inclusion of BSA in the SRTF produced a higher rate of protein secretion into the lumen than was obtained by perfusing SRTF containing no BSA $(P<0 \cdot 01)$. However, Fig. 2 shows that BSA did not stimulate protein secretion as much as nRTF (unmodified nRTF and the high $M_{\mathrm{r}}$ fraction of nRTF) which contained an equivalent amount of protein $(P<0.01)$.

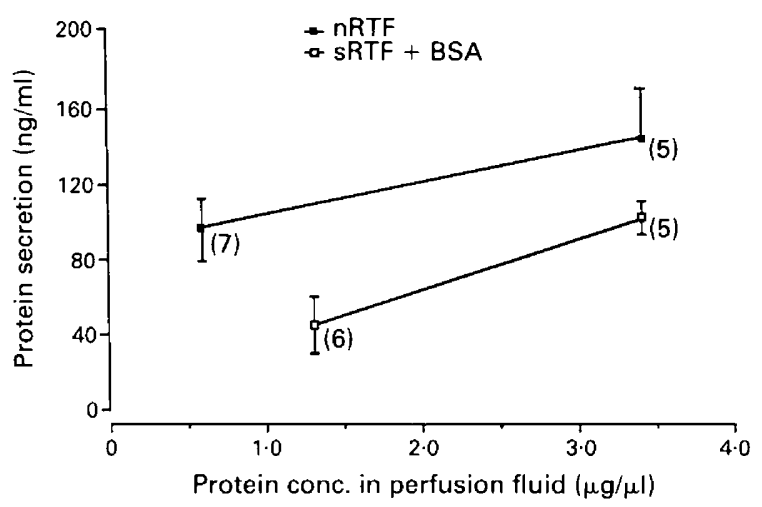

Fig. 2. Protein secretion into zone $1 \mathrm{~A}$ of the ductus epididymidis during perfusion with unmodified nRTF and the high $M_{\mathrm{r}}$ fraction of nRTF (- -) or sRTF containing 1.3 or $3.4 \mu \mathrm{g}$ $\mathrm{BSA} / \mu \mathrm{l}(-\square-)$. The number of animals is shown in parentheses.

Polyacrylamide gel electrophoresis of perfusates (Fig. 3) from 4 animals perfused with nRTF and 4 perfused with SRTF showed that the ductus secreted 3 proteins which were not present in blood. One of these (of $M_{\mathrm{r}} 19000$ ) formed a dense band in all gels; a protein of $M_{\mathrm{r}} 22000$ also 
formed a dense band in gels, but only for perfusates of 2 rats perfused with nRTF and 2 rats perfused with sRTF; and a protein of $M_{\mathrm{r}} 60000$ formed a moderately dense band in gels for perfusates from 1 rat perfused with $\mathrm{nRTF}$ and 3 rats perfused with $\mathrm{R}$ TF. In addition a moderately dense band corresponding to a protein of $M_{\mathrm{r}} 30000$, which was not present in samples of blood, was present in all gels of nRTF, and in gels of perfusates from 2 rats (of the 4 rats examined) which were perfused with sRTF. Several proteins with the same molecular weight as blood proteins were present in gels of perfusates (Fig. 3), including one with an $M_{\mathrm{r}}$ of 83000 which was present in perfusates of 3 animals perfused with $\mathrm{SRTF}$ and 3 perfused with $\mathrm{nRTF}$. It was interpreted that there was no difference in the pattern of protein secretion into the two perfusion fluids.

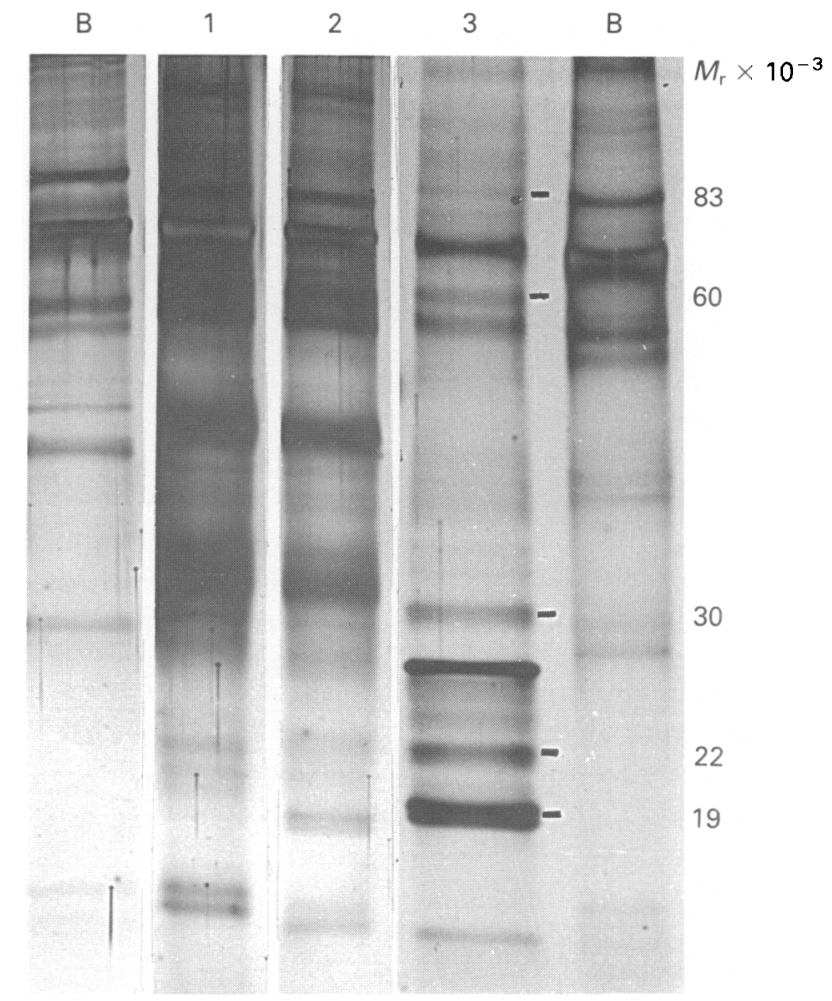

Fig. 3. Photograph of denatured linear-gradient polyacrylamide gel of blood plasma (B), nRTF (1) and perfusates after perfusing zone $1 \mathrm{~A}$ of the epididymis with nRTF (2) or sRTF (3). Gels were loaded with $0.25 \mu \mathrm{g}$ protein for B, lanes 1 and 3 or $0.125 \mu \mathrm{g}$ protein for lane 2 . Silver stain.

\section{Discussion}

As Nicander et al. (1983) indicated that apoptosis of the duct epithelium starts in zone $1 \mathrm{~A}$ of the rat epididymis $6 \mathrm{~h}$ after efferent duct ligation, yet in the studies described in this report there was no effect of perfusing the duct with sRTF, it is suggested that the perfusion somehow delays the regression associated with preventing testicular fluid from entering the initial segment.

It is concluded from the studies described in this report that sheep rete testis fluid contains a factor or factors which stimulates protein secretion by the epithelium lining zone $1 \mathrm{~A}$ of the ductus epididymidis. The activity is probably due to a protein or proteins as it is in a fraction with a molecular weight of $>10000$ and is sensitive to proteases. Some of the activity may be due to 
albumin which is present in rete testis fluid (Koskimies \& Kormano, 1975; Skinner et al., 1987), but it would not account for much of the activity observed in the nRTF used in these studies as albumin represents only $11-17 \%$ of the protein present in the fluid (Koskimies \& Kormano, 1973; Skinner et al., 1987) and the potency of albumin is less than one-third of the protein in nRTF (Fig. 2). Albumin is also transported across the duct mucosa from blood into the lumen of the ductus epididymidis (see Fig. 3 of this study; Brooks \& Higgins, 1980). Several other biologically active macromolecules have been identified in rete testes fluid, including androgen-binding protein (Griswold, 1986), seminiferous growth factor (Feig et al., 1980), $\alpha_{2}$-macroglobulin (Johnson \& Setchell, 1968) and cellular retinol binding protein (Kato et al., 1985), but it is premature to speculate on their involvement in regulating protein secretion in the epididymis.

The finding that nRTF stimulates protein secretion by zone $1 \mathrm{~A}$ of the epididymis of the rat supports studies on the effects of efferent duct ligation (Brooks \& Higgins, 1980; Jones et al., $1980 \mathrm{a}, \mathrm{b})$ which showed that protein synthesis and secretion in the initial segments of the rat epididymis are altered by preventing the testicular effluent from flowing into the ductus. However, it should not be assumed that the perfusion studies described in this report are examining the same response that was studied following efferent duct ligation as the latter studied protein secretion at a time when there would be considerable intracellular structural reorganization of the principal cells, whereas there was no such change during the period of perfusion described in this report (see Fig. 1). Also, Jones et al. (1980b) found that the main effect of efferent duct ligation was on the synthesis of specific proteins $\left(M_{\mathrm{r}} 23000\right.$ and 80000$)$ whereas in this study the secretagogue effect on $\mathrm{nRTF}$ seemed to be mainly on the rate of protein secretion.

It is also concluded from the present studies that zone $1 \mathrm{~A}$ of the epididymis of the rat secretes protein with an $M_{\mathrm{r}}$ of 19000 which is not present in blood. This protein probably corresponds to the 2 proteins, with $M_{\mathrm{r}}$ values of 18500 and 19000 , described by Jones et al. (1980a). The duct sometimes secretes other proteins which are not present in blood $\left(M_{\mathrm{r}} 22000, M_{\mathrm{r}} 30000\right)$. It is suggested that the protein with a $M_{\mathrm{r}}$ of 22000 corresponds to the protein with an $M_{\mathrm{r}}$ of 23000 which Jones et al. (1980b) found to be synthesized by the 'initial segment' of the rat, and probably the protein with an $M_{\mathrm{r}}$ of 30000 corresponds to the protein with an $M_{\mathrm{r}}$ of 32000 which Jones et al. (1980a) found to be synthesized by the 'caput epididymidis' of the rat. Jones et al. $(1980 \mathrm{a}, \mathrm{b})$ also found that the 'initial segment' secretes a protein of $M_{\mathrm{r}} 80000$ and it is suggested that this corresponds to the protein of $M_{\mathrm{r}} 83000$ which was secreted into most perfusion fluids.

The finding in this study that there is little net fluid transport across the duct mucosa of zone $1 \mathrm{~A}$ is in agreement with our earlier work (Jones \& Jurd, 1987) which showed that the fluid which was reabsorbed between the rete testis and zone 2 of the ductus epididymidis $(84 \%$ of the fluid: Hinton et al., 1980) could be accounted for by reabsorption in the ductuli efferentes as they were estimated to reabsorb $83-92 \%$ of the fluid leaving the rete testis. Although Djakiew et al. (1986) recorded an increase in spermatocrit value in micropuncture samples taken from zones $1 \mathrm{~A}$ and 2 , this should be interpreted with some caution as micropuncture samples of zone 1 are contaminated with stereocilia (Jones et al., 1987) and result in a diffuse boundary between the sperm and supernatant layers in a spermatocrit.

This work was supported by a grant from the Australian Research Grants Scheme.

\section{References}

Benoit, J. (1926) Recherches anatomiques, cytologiques et histophysiologiques sur les voies excrétrices du testicule, chez les mammifères. Archs d'anat. Histol. Embryol. 5, 173-412.

Bradford, M.M. (1976) A rapid and sensitive method for the quantitation of microgram quantities of protein utilizing the principle of protein dye binding. Analyt. Biochem. 72, 248-254.
Brooks, D.E. \& Higgins, S.J. (1980) Characterization and androgen-dependence of proteins associated with luminal fluid and spermatozoa in the rat epididymis. J. Reprod. Fert. 59, 363-375.

Djakiew, D., Griswold, M.D., Lewis, D.M. \& Dym, M. (1986) Micropuncture studies of receptor-mediated endocytosis of transferrin in the rat epididymis. Biol. Reprod. 34, 691-699. 
Fawcett, D.W. \& Hoffer, A.P. (1979) Failure of exogenous androgen to prevent regression of the initial segments of the rat epididymis after efferent duct ligation or orchidectomy. Biol. Reprod. 20, 162-181.

Feig, L.A., Bellvé, A.R., Erickson, N.H. \& Kalgsrun, M. (1980) Sertoli cells contain a mitogenic polypeptide. Proc. natn. Acad. Sci., USA 77, 47744778.

Griswold, M.D. (1986) Biosynthesis of transferrin and transferrin mRNA by cultured Sertoli cells. Fedn Proc. Fedn Am. Socs exp. Biol. 45, 2291-2298.

Gustafsson, B. (1966) Luminal contents of the bovine epididymis under conditions of reduced spermatogenesis, luminal blockage and certain sperm abnormalities. Acta vet. scand., Suppl. 17, 1-80.

Hinton, B.T., White, R.W. \& Setchell, B.P. (1980) Concentrations of myo-inositol in the luminal fluid of the mammalian testis and epididymis. J. Reprod. Fert. 58, 395-399.

Johnson, M.H. \& Setchell, B.P. (1968) Protein and immunoglobulin content of rete testis fluid of rams. J. Reprod. Fert. 17, 403-406.

Jones, R. \& Brown, C.R. (1982) Association of epididymal secretory proteins showing $\alpha$-lactalbumin-like activity with the plasma membrane of rat spermatozoa. Biochem. J. 206, 161-164.

Jones, R., Brown, C.R., von Glos, K.I. \& Parker, M.G. (1980a) Hormonal regulation of protein synthesis in the rat epididymis. Biochem. J. 188, 667-676.

Jones, R., von Glos, K.I. \& Brown, C.R. (1980b) The synthesis of a sperm-coating protein in the initial segment of the rat epididymis is stimulated by factors in testicular fluid. IRCS Medical Science: Biochemistry; Cell and Membrane Biology; Physiology; Reproduction, Obstetrics \& Gynaecology 8, 56.

Jones, R.C. (1987) Changes in protein composition of the luminal fluids along the epididymis of the tammar, Macropus engenii. J. Reprod. Fert. 80, 193-199.

Jones, R.C. \& Clulow, J. (1987a) Regulation of the elemental composition of the epididymal fluids in the tammar, Macropus engenii. J. Reprod. Fert. 81, 583-590.

Jones, R.C. \& Clulow, J. (1987b) Fluid absorption and sperm maturation and storage in the epididymis. In Proc. 1st Congr. Asian Oceania Physiol. Soc. pp. 229-240. Eds C. Pholpramool \& R. Sudsuang. The Physiological Society (Thailand), Bangkok.

Jones, R.C. \& Jurd, K.M. (1987) Structural differentiation and fluid reabsorption in the ductuli efferentes testis of the rat. Aust. J. biol. Sci. 40, 79-90.
Jones, R.C., Hinds, L.A. \& Tyndale-Biscoe, C.H. (1984) Ultrastructure of the epididymis of the tammar, Macropus eugenii, and its relationship to sperm maturation. Cell Tiss. Res. 237, 525-535.

Jones, R.C., Clulow, J., Stone, G.M. \& Setchell, B.P. (1987) The role of the initial segments of the epididymis in sperm maturation in mammals. In New Horizons in Sperm Cell Research, pp. 65-71. Ed. H. Mohri. Japan Sci. Soc. Press, Tokyo.

Kato, M., Sung, W.K., Kato, K. \& Goodman, D.S. (1985) Immunohistochemical studies on the localization of cellular retinol-binding protein in rat testis and epididymis. Biol. Reprod. 32, 173-189.

Koskimies, A.I. \& Kormano, M. (1973) The proteins in fluids from the seminiferous tubules and rete testis of the rat. J. Reprod. Fert. 34, 433-444.

Koskimies, A.I. \& Kormano, M. (1975) Proteins in fluids from different segments of the rat epididymis. $J$. Reprod. Fert. 43, 345-348.

Moniem, K.A., Glover, T.D. \& Lubicz-Nawrocki, C.W. (1978) Effects of duct ligation and orchidectomy on histochemical reactions in the hamster epididymis. $J$. Reprod. Fert. 54, 173-176.

Nicander, L., Osman, D.I., Ploen, L., Bugge, H.P. \& Kvisgaard, K.N. (1983) Early effects of efferent ductuli ligation on the proximal segment of the rat epididymis. Int. J. Androl. 6, 91-102.

Reid, B.L. \& Cleland, K.W. (1957) The structure and function of the epididymis I. The histology of the rat epididymis. Aust. J. Zool. 5, 223-246.

Setchell, B.P., Scott, T.W., Voglmayr, J.K. \& Waites, G.M.H. (1969) Characteristics of testicular spermatozoa and the fluid which transports them into the epididymis. Biol. Reprod. 1 (Suppl.), 40-66.

Skinner, M.K., Dean, L., Karmally, K. \& Fritz, I.B. (1987) Rete testis fluid (RTF) proteins: purification and characterization of RTF albumin. Biol. Reprod. $37,135-146$.

Suominen, J. \& Setchell, B.P. (1972) Enzymes and trypsin inhibitor in the rete testis fluid of rams and boars. $J$. Reprod. Fert. 30, 235-245.

Tsonis, C.G., Quigg, H., Lee, V.W.K., Leversha, L., Trounson, A.O. \& Findlay, J.K. (1983) Inhibin in individual ovine follicles in relation to diameter and atresia. J. Reprod. Fert. 67, 83-90.

Received 31 May 1989 